\title{
PENGARUH DOSIS EKSTRAK AIR DAUN BAYAM MERAH (Amaranthus tricolor L.) TERHADAP JUMLAH ERITROSIT DAN KADAR HEMOGLOBIN PADA TIKUS PUTIH (Rattus norvegicus): SEBAGAI SUMBER BELAJAR BIOLOGI SISWA SMA KELAS XI PADA MATERI PEMBELAJARAN SISTEM SIRKULASI PADA MANUSIA
}

\author{
Ratna Putri Aryani, Trianik Widyaningrum
}

\begin{abstract}
ABSTRAK
$\mathrm{P}$ enelitian ini bertujuan untuk mengetahui pengaruh dosis ekstrak air daun bayam merah (Amaranthus tricolor L.) terhadap jumlah eritrosit dan kadar hemoglobin pada tikus putih (Rattus norvegicus), serta untuk mengetahui dosis ektrak air daun bayam merah yang paling perpengaruh terhadap jumlah eritrosit dan kadar hemoglobin serta pemanfaatan hasil penelitian dosis ekstrak air daun bayam merah terhadap jumlah eritrosit dan kadar hemoglobin tikus putih sebagai sumber belajar biologi SMA siswa kelas XI pada materi pembelajaran sistem sirkulasi pada manusia.

Penelitian ini menggunakan Rancangan Acak Lengkap (RAL) yang terdiri dari 1 faktor yaitu dosis ekstrak air daun bayam merah dengan perlakuan yaitu A (1,25\% setara dengan dosis $0,125 \mathrm{gram} / \mathrm{KgBB}), \mathrm{B}(2,5 \%$ setara dengan dosis $0,25 \mathrm{gram} / \mathrm{KgBB}), \mathrm{C}$ ( $5 \%$ setara dengan dosis 0,5 gram/KgBB), D (10\% setara dengan dosis 1 gram/KgBB), dan kontrol (tanpa pemberian ekstrak air daun bayam merah). Perhitungan jumlah eritrosit dan kadar hemoglobin dilakukan pada hari ke-20 setelah pemberian ekstrak air daun bayam merah. Untuk mengetahui pengaruh dosis ekstrak air daun bayam merah terhadap jumlah eritrosit pada tikus putih dilakukan analisis regresi, untuk mengetahui perbedaan antar perlakuan terhadap jumlah eritrosit dan kadar hemoglobin dilakukan analisis varian (ANAVA) dan dilanjutkan dengan uji LSD.

Hasil penelitian menunjukkan bahwa dosis ekstrak air daun bayam merah berpengaruh terhadap jumlah eritrosit dan kadar hemoglobin pada tikus putih. Dosis yang paling berpengaruh adalah perlakuan D (dosis ekstrak air daun bayam merah 1 gram $/ \mathrm{KgBB}$ ). Hasil penelitian ini diharapkan dapat digunakan sebagai sumber belajar biologi siswa SMA kelas XI pada materi pembelajaran sistem sirkulasi pada manusia dalam bentuk power point.
\end{abstract}

Kata kunci : Dosis ekstrak air daun bayam merah (Amaranthus tricolor L.), Tikus putih (Rattus norvegicus) Jumlah eritrosit, kadar hemoglobin, dan Sumber bel 


\section{PENDAHULUAN}

Tanaman yang tumbuh di muka bumi ini diciptakan untuk memenuhi kebutuhan manusia misalnya untuk bahan makanan, obat-obatan dan lain sebagainya. Bahkan menurut Pilnius dalam (Tjitrosoepomo,1994), semua tumbuhan mempunyai daya pengobatan. Budaya bangsa yang berkaitan pemeliharaan kesehatan dan pengobatan penyakit, lebih banyak menggunakan tumbuhan. Hal ini didukung oleh melimpahnya berbagai macam flora yang berkhasiat di tanah air (Sodibyo, 1998). Hal ini memacu untuk melakukan penyelidikan ilmiah guna memperoleh kepastian khasiat tumbuhan tersebut.

Pemanfaatan tanaman sebagai obat sudah lama dilakukan oleh manusia. Tumbuhan mempunyai manfaat untuk obat berbagai penyakit. Tumbuhan yang merupakan bahan baku obat tradisional tersebut tersebar hampir di seluruh wilayah Indonesia (Anonim, 2000). Salah satu tumbuhan tersebut adalah bayam merah (Amaranthus tricolor. L).

Bayam yang biasa dikonsumsi sebagai sayuran disebut dengan istilah bayam cabutan atau bayam sekul. Terdapat tiga macam varietas bayam yang termasuk ke dalam Amaranthus tricolor L. yaitu bayam hijau, bayam merah (Blitum rubum), yang berwarna hijau keputih-putihan. Daun dan batang bayam merah mengandung cairan yang ber- warna merah. Bayam merah sangat kaya akan vitamin A. Vitamin ini berperan dalam fungsi penglihatan. Kandungan yang paling besar pada bayam adalah zat besi. Bagi wanita yang mengalami proses menstruasi, zat besi bisa mengganti sel darah yang hilang karena zat besi yang ada dalam bayam merupakan komponen penting untuk membentuk hemoglobin (Anonim, 2009). Berikut adalah morfologi bayam merah:

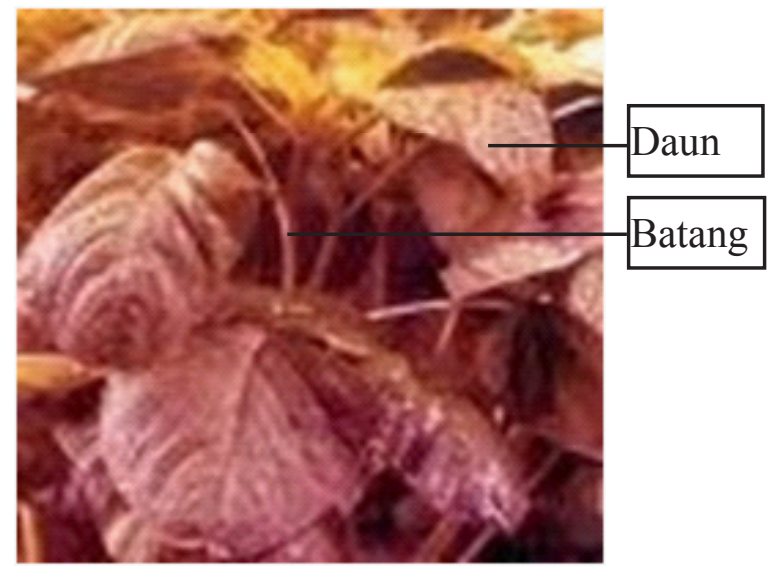

Zat besi dan protein merupakan komponen utama pembentuk hemoglobin $(\mathrm{Hb})$ yang terdapat dalam sel darah merah. Vitamin C merupakan salah satu faktor yang meningkatkan arbsorbsi zat besi. Vitamin C membantu proses reduksi besi dalam saluran pencernakan dari bentuk Feri (Fe+++) menjadi bentuk Fero $(\mathrm{Fe}++)$ yang mudah diserap oleh tubuh (Winarno, 1991).

Sel darah merah memerlukan protein karena strukturnya terbentuk dari asam amino. Selain itu juga memerlukan zat besi, sehingga untuk pembentukan sel darah merah baru memerlukan protein dan zat besi sehingga diperlukan diet seimbang yang berisi 
zat besi (Pearce, 1999). Sel darah merah terdiri dari air (65\%), Hb (33\%), dan sisanya terdiri dari sel stroma, lemak, mineral, vitamin dan bahan organik lainnya dan ion $\mathrm{K}$ (Kusumawati, 2004).

Pengaruh hemoglobin di dalam sel darah merah menyebabkan timbulnya warna merah pada darah karena mempunyai kemampuan untuk mengangkut oksigen. Haemoglobin adalah senyawa organik yang komplek dan terdiri dari empat pigmen porpirin merah (heme) yang masing-masing mengandung iron dan globin yang merupakan protein globural dan terdiri dari empat asam amino. Haemoglobin bergabung dengan oksigen didalam paru-paru yang kemudian terbentuk haemoglobin yang selanjutnya melepaskan oksigen ke sel-sel jaringan didalam tubuh (Frandson, 1992).

Untuk mengetahui efek dari suatu zat yang akan digunakan dan dimanfaatkan oleh manusia, perlu dilakukan penelitan di Laboratorium. Pada penelitian ini digunakan tikus putih (Rattus norvegicus), karena hewan ini memiliki siklus estrus yang jelas, mudah dipelihara, mudah beradaptasi dengan perlakuan dan hewan ini tersedia dalam jumlah banyak.

Berdasar latar belakang tersebut, maka tujuan penelitian ini adalah untuk mengetahui pengaruh ekstrak air daun bayam merah (Amaranthus tricolar L.) terhadap jumlah eritrosit dan kadar hemoglobin tikus putih
(Rattus norvegicus), dosis ekstrak air bayam merah (Amaranthus tricolar L.) yang mempengaruhi jumlah eritrosit dan kadar hemoglobin tikus putih (Rattus norvegicus)

\section{METODE PENELITIAN}

\section{A. Alat Dan Bahan}

Alat yang digunakan dalam penelitian ini adalah:
a. Kandang pemeliharaan dan perlengka- pan milik UPHP UGM.

b. Pemeriksaan eritrosit dan hemoglobin antara lain pipet, kapas, jarum hemotologi analyzer.
c. Timbangan analitik kepekaan 0,001 gram

d. Pembuatan ekstrak antara lain pisau, almari pendingin, mortar.

e. Alat injeksi (syringe) kapasitas $3 \mathrm{ml}$ yang ujungnya diberi kanul digunakan untuk memberikan ekstrak ke tikus putih secara oral.

Bahan yang digunakan dalam penelitian ini adalah tikus putih (Rattus norvegicus) 15 ekor, ekstrak daun bayam (Amaranthus tricolor $L$ ), pakan tikus, larutan Hayem (untuk melisiskan darah sehingga eritrositdapat terlihat di mikroskop, $\mathrm{HCl}$ 0,1 $\mathrm{N}$, Aquades untuk pengencer ekstrak bayam merah, EDTA dan alkohol. 


\section{Variabel Penelitian}

\section{Variabel bebas}

Variabel bebas dalam penelitian ini adalah variasi dosis ekstrak air bayam merah selama 20 hari yang dikelompokkan sebagai berikut:

\section{K : Kontrol}

A : Perlakuan $1.25 \%$ setara dengan dosis $0,125 \mathrm{gram} / \mathrm{KgBB}$

B : Perlakuan 2,5\% setara dengan dosis 0,25 $\mathrm{gram} / \mathrm{KgBB}$

$\mathrm{C}$ : Perlakuan $5 \%$ setara dengan dosis 0,5 $\operatorname{gram} / \mathrm{KgBB}$

D : Perlakuan 10\%, setara dengan dosis 1 gram $/ \mathrm{KgBB}$

\section{Variabel terikat}

Variabel terikat pada penelitian ini adalah sebagai berikut:

a. Jumlah sel darah merah / eritrosit (juta/ $/ \mathrm{mm}^{3}$ ), yang dihitung pada akhir perlakuan yaitu setelah 20 hari perlakuan.

b. Kadar hemoglobin (gram/100ml darah), yang dihitung pada akhir perlakuan yaitu setelah 20 hari perlakuan.

\section{Cara Kerja}

\section{Tahap persiapan \\ a. Aklimasi tikus}

Sebelum memberi perlakuan, tikus putih di aklimasi selama 1 minggu yang bertujuan agar tikus putih dapat beradaptasi dengan lingkungan yang baru sehingga diperoleh hewan percobaan yang benar-benar sehat dan normal.

\section{b. Kandang}

Penelitian yang dilakukan, tikus putih akan dipelihara dalam kandang yang terbuat dari bak plastik dengan penutup kawat. Alas kandang ditaburi serbuk gergaji yang bertujuan untuk mengurangi kedinginan dan mengurangi bau tidak sedap dari kotoran tikus putih, maupun pakan yang diberikan. Jumlah kandang dengan 5 macam perlakuan dan setiap perlakuan dilakukan 3 kali pengulangan.

\section{c. Pakan}

Jenis makanan yang diberikan pada tikus putih adalah pellet AD2 yang diperoleh dari UPHP UGM. Dengan pemberian 3 kali sehari sebanyak 10\% BB ( \pm 20gram $)$ / ekor/ hari (Anonim, 2010).

\section{d. Pembuatan ekstrak air daun bay- am merah}

Pembuatan ekstrak menggunakan daun bayam merah yang sudah disortir, dicuci, dipotong, kemudian dikeringkan dalam almari pengering dengan suhu $38^{\circ} \mathrm{C}$ selama $3 \times 24$ jam. Setelah kering daun diserbuk dan dibuat ekstrak dengan pelarut aquades lalu dimixer selama 30 menit dan dimaserasi 24 jam kemudian direndam dalam pelarut. Proses berikutnya menfiltrasi hingga diperoleh filtrate. Filtrate dievaporasi hingga terbentuk ekstrak 
murni kemudian dilakukan pengenceran sesuai kebutuhan.

\section{Tahap perlakuan}

Selanjutnya hewan uji diberikan perlakuan secara oral dengan dosis-dosis yang telah ditentukan yaitu:

\section{K : Kontrol}

A : Perlakuan $1.25 \%$ setara dengan dosis $0,125 \mathrm{gram} / \mathrm{KgBB}$

B : Perlakuan 2,5\% setara dengan dosis $0,25 \mathrm{gram} / \mathrm{KgBB}$

C : Perlakuan 5\% setara dengan dosis 0,5 $\mathrm{gram} / \mathrm{KgBB}$

D : Perlakuan 10\%, setara dengan dosis 1 gram $/ \mathrm{KgBB}$

Pemberian perlakuan dilakukan setiap hari dan dalam sehari diberi ekstrak air daun bayam merah 1 kali selama 20 hari. Ekstrak diberi secara oral pada tikus putih dengan menggunakan syringe yang diberi kanal pada ujungnya. Ekstrak air daun bayam merah diberikan setiap hari setelah tikus putih ditimbang terlebih dahulu untuk menentukan jumlah ekstrak.

\section{Tahap pengambilan data}

Setelah tahap perlakuan pada hari ke 20 dilakukan pengambilan sampel darah melalui vena mata. Kemudian dihitung jumlah eritrosit dan kadar hemoglobin darah tikus putih tersebut.

\section{Tahap pengamatan}

Untuk melakukan tahap pengamatan mengunakan acuan buku petunjuk prakti- kum Fisiologi hewan :

\section{a. Pembuatan sampel darah}

Darah segar untuk keperluan penelitian agar tidak mudah menggumpal digunakan EDTA (Ethylene Diamin Tetra Acetic Acit).

Adapun langkah-langkah pembuatannya adalah :

1. Diambil 1 garam EDTA kemudaian dimasukkan ke dalam tabung reaksi yang berisi darah segar $50 \mathrm{ml}$ kemudian tabung diputar agar serbuk antikoagulan darah tercampur dalam darah.

2. EDTA digunakan agar darah tikus tidak mudah menggumpal.

\section{b. Perhitungan jumlah eritrosit dan}

\section{kadar hemoglobin.}

Adapun langkah-langkah perhitungan jumlah eritrosit dan kadar hemoglobin adalah sebagai berikut :

1. Sebelum darah dimasukkan kedalam alat hemocyto analyzer untuk dibaca, darah diputar dan dibalik sampai tidak ada endapan darah yang menngumpal.

2. Dimasukkan ke dalam sampel holder kemudian ditekan star (SIPPER).

3. Hasil secara otomatis akan tertampil pada layar dan tercetak pada kertas printer. 


\section{HASIL DAN PEMBAHASAN}

\section{Hasil}

Berdasarkan penelitian yang dilakukan selama 20 hari terhadap tikus putih (Rattus norvegicus) diperoleh hasil antara lain rata- rata jumlah eritrosit dan rata-rata kadar hemoglobin.

Tabel 1. Rata-rata jumlah eritrosit selama 20 hari pemberian ekstrak bayam merah (Amaranthus tricolor .L)

\begin{tabular}{|c|c|c|c|}
\hline \multirow{2}{*}{ Perlakuan } & \multirow{2}{*}{$\begin{array}{c}\text { Dosis ekstrak air daun bayam } \\
\text { merah }\end{array}$} & \multicolumn{2}{|c|}{ Rerata jumlah eritrosit tikus putih } \\
\hline & & Ulangan & Jumlah $/ \mu \mathrm{L}$ \\
\hline Kontrol & Tanpa pemberian ekstrak & \begin{tabular}{|l}
1 \\
2 \\
3 \\
\end{tabular} & $\begin{array}{l}6,02 \times 10^{6} \\
6,04 \times 10^{6} \\
6,06 \times 10^{6} \\
\end{array}$ \\
\hline \multicolumn{3}{|c|}{ Rerata \pm SD } & $6,04 \pm 0,02 \times 10^{6} / \mu \mathrm{L}$ \\
\hline A & $0.125 \mathrm{gram} / \mathrm{KgBB}$ & $\begin{array}{l}1 \\
2 \\
3\end{array}$ & $\begin{array}{l}6,05 \times 10^{6} \\
6,06 \times 10^{6} \\
6,07 \times 10^{6}\end{array}$ \\
\hline \multicolumn{3}{|c|}{ Rerata \pm SD } & $6,06 \pm 0,01 \times 10^{6} / \mu \mathrm{L}$ \\
\hline B & $0,25 \mathrm{gram} / \mathrm{KgBB}$ & $\begin{array}{l}1 \\
2 \\
3\end{array}$ & $\begin{array}{l}6,11 \times 10^{6} \\
6,12 \times 10^{6} \\
6,13 \times 10^{6} \\
\end{array}$ \\
\hline \multicolumn{3}{|c|}{ Rerata \pm SD } & $6,12 \pm 0,01 \times 10^{6} / \mu L$ \\
\hline $\mathrm{C}$ & $0,5 \mathrm{gram} / \mathrm{KgBB}$ & $\begin{array}{l}1 \\
2 \\
3\end{array}$ & $\begin{array}{l}8,32 \times 10^{6} \\
8,24 \times 10^{6} \\
8,29 \times 10^{6}\end{array}$ \\
\hline \multicolumn{3}{|l|}{ Rerata \pm SD } & $8,28 \pm 0,04 \times 10^{6} / \mu \mathrm{L}$ \\
\hline $\mathrm{D}$ & $1 \mathrm{gram} / \mathrm{KgBB}$ & $\begin{array}{l}1 \\
2 \\
3 \\
\end{array}$ & $\begin{array}{l}9,37 \times 10^{6} \\
9,31 \times 10^{6} \\
9,29 \times \times 10^{6} \\
\end{array}$ \\
\hline \multicolumn{3}{|c|}{ Rerata \pm SD } & $9,32 \pm 0,04 \times 10^{6} / \mu L$ \\
\hline
\end{tabular}

Tabel 1. Rata-rata jumlah eritrosit selama 20 hari pemberian ekstrak bayam merah (Amaranthus tricolor .L)

Berdasarkan Tabel 1 terlihat bahwa rerata eritosit tikus putih (Rattus norvegicus) terbesar selama 20 hari pemeliharan adalah pada perlakuan D (dengan dosis 1 gram/KgBB) dan jumlah eritosit tikus putih (Rattus norvegicus) terkecil adalah pada perlakuan Kontrol (tanpa pemberian ekstrak).

Untuk mengetahui pengaruh ekstrak air daun bayam merah (Amarantus tricolor JURNAL BIOEDUKATIKA 


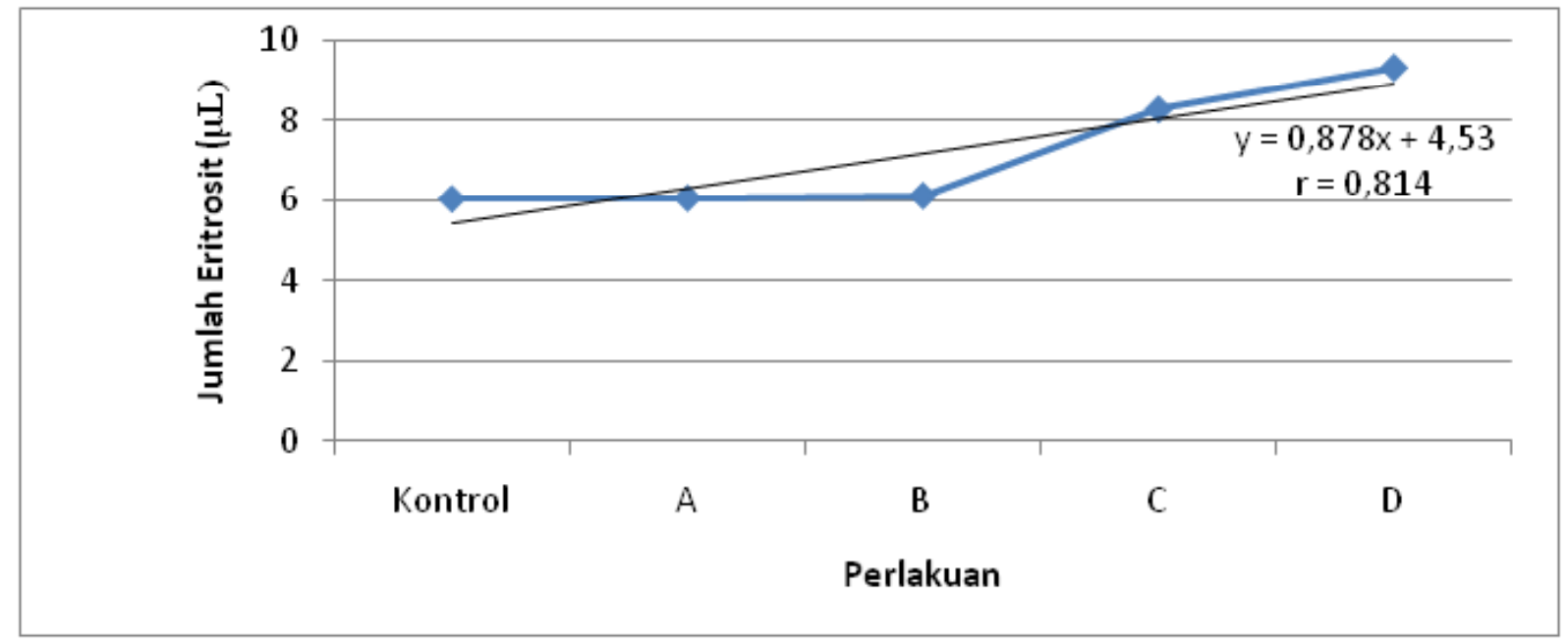

Gambar 2. Grafik hasil analisis regresi pengaruh ekstrak air daun bayam merah (Amarantus tricolor L.) terhadap jumlah eritosit pada tikus putih (Rattus norvegicus)

Keterangan :

K : Kontrol

A : Ekstrak air daun bayam merah $1.25 \%$ setara dengan dosis 0,125 gram $/ \mathrm{KgBB}$

B : Ekstrak air daun bayam merah $2,5 \%$ setara dengan dosis $0,25 \mathrm{gram} / \mathrm{KgBB}$

C : Ekstrak air daun bayam merah 5\% setara dengan dosis 0,5 gram $/ \mathrm{KgBB}$

D : Ekstrak air daun bayam merah 10\% setara dengan dosis 1 gram $/ \mathrm{KgBB}$

Berdasarkan Gambar 2 dapat dilihat bahwa hasil penelitian menunjukan hubungan linear sehingga memberi pengaruh positif terhadap ekstrak air daun bayam merah (Amarantus tricolor L.) terhadap jumlah eritrosit pada tikus putih (Rattus norvegicus). Bila dilihat dari gambar tersebut bahwa semakin tinggi dosis yang diberikan maka jumlah eritrosit semakin meningkat.

Untuk mengetahui perbedaan antar perlakuan dilakukan analisis varian. Adapun ringkasan hasil anava rata-rata jumlah eritrosit disajikan pada Tabel 2.

\begin{tabular}{|c|c|c|c|c|c|}
\hline SV & DB & JK & KT & F hitung & F Tabel 5\% \\
\hline Perlakuan & 4 & 28.463 & 7.116 & 8969.508 & 3,48 \\
\hline Galat & 10 & .008 & .001 & & \\
\hline Total & 14 & 28.471 & & & \\
\hline
\end{tabular}

Tabel 2. Hasil anava untuk rata jumlah eritrosit pada tikus putih

Berdasarkan Tabel 2. Terlihat pada taraf uji 5\% pemberian ekstrak air daun bayam merah (Amarantus tricolor L.) terhadap jumlah eritrosit pada tikus putih (Rattus norvegicus) dengan dosis yang berbeda-beda 78 menimbulkan perbedaan jumlah eritrosit yang berbeda-beda juga yang terbukti dengan nilai F hitung (8969.508) > F Tabel $(3,48)$.

Untuk mengetahui kelompok-kelompok yang memiliki perbedaan yang nyata, maka dapat diketahui hasilnya dengan uji VOL. 1 NO. 1 JULI 2013 HAL. 1 - 96 
LSD dengan hasil seperti pada Tabel 3.

\begin{tabular}{|c|c|c|}
\hline Perlakuan & $\begin{array}{c}\text { Rerata } \\
\text { eritrosit }\end{array}$ & LSD5\% $=0,04$ \\
\hline Kontrol & 6.04 & $\mathrm{a}$ \\
\hline $\mathrm{A}$ & 6.06 & $\mathrm{a}$ \\
\hline $\mathrm{B}$ & 6.12 & $\mathrm{~b}$ \\
\hline $\mathrm{C}$ & 8.28 & $\mathrm{c}$ \\
\hline $\mathrm{D}$ & 9.32 & $\mathrm{~d}$ \\
\hline
\end{tabular}

Tabel 3. Hasil uji statistik LSD jumlah eritrosit dari kelompok perlakuan

Keterangan angka-angka yang diikuti oleh huruf yang sama menunjukkan tidak ada beda nyata :

K : Kontrol

A : Perlakuan $1.25 \%$ setara dengan dosis $0,125 \mathrm{gram} / \mathrm{KgBB}$

B : Perlakuan 2,5\% setara dengan dosis $0,25 \mathrm{gram} / \mathrm{KgBB}$

C : Perlakuan 5\% setara dengan dosis $0,5 \mathrm{gram} / \mathrm{KgBB}$

D : Perlakuan 10\%, setara dengan dosis $1 \mathrm{gram} / \mathrm{KgBB}$

Berdasarkan hasil uji LSD pada Tabel

3 menunjukkan bahwa sebagian perlakuan menunjukkan adanya beda nyata antar perlakuan. Hal ini berarti bahwa pemberian ekstrak air daun bayam merah (Amarantus tricolor L.) terhadap jumlah sel darah merah pada tikus putih (Rattus norvegicus) dengan dosis yang berbeda-beda dapat menimbulkan perbedaan jumlah sel darah merah yang berbeda-beda pula. Dari hasil uji LSD di atas maka pada kontrol (tanpa pemberian ekstrak) dan perlakuan A $(1,25 \%)$ keduanya menunjukkan tidak adanya beda nyata. Sedangkan untuk perlakuan B $(2.5 \%)$ dapat dilihat ada beda nyata begitu juga dengan perlakuan $\mathrm{C}$ (5\%) dan perlakuan D (10\%).

Rata-rata pertambahan berat tikus putih pada akhir penelitian dapat dilihat seperti pada Tabel 4.

\begin{tabular}{|c|c|c|c|}
\hline \multirow{2}{*}{ Perlakuan } & \multirow{2}{*}{ Dosis air daun bayam merah } & \multicolumn{2}{|c|}{ Rerata pertambahan jumlah hemoglobin } \\
\hline & & Ulangan & Jumlah / $\mu \mathrm{L}$ \\
\hline $\mathrm{K}$ & $\begin{array}{c}0 \text { gram/KgBB tanpa pembe- } \\
\text { rian ekstrak }\end{array}$ & $\begin{array}{l}1 \\
2 \\
3\end{array}$ & \begin{tabular}{|l|}
$12,40 \mathrm{~g} / \mathrm{dL}$ \\
$12,30 \mathrm{~g} / \mathrm{dL}$ \\
$12,32 \mathrm{~g} / \mathrm{dL}$
\end{tabular} \\
\hline \multicolumn{3}{|l|}{ Rerata \pm SD } & $12,34 \pm 0,05 \mathrm{~g} / \mathrm{dL}$ \\
\hline A & $0,125 \mathrm{gram} / \mathrm{KgBB}$ & $\begin{array}{l}1 \\
2 \\
3\end{array}$ & $\begin{array}{l}12,30 \mathrm{~g} / \mathrm{dL} \\
12,30 \mathrm{~g} / \mathrm{dL} \\
12,40 \mathrm{~g} / \mathrm{dL}\end{array}$ \\
\hline \multicolumn{3}{|l|}{ Rerata \pm SD } & $12,33 \pm 0,06 \mathrm{~g} / \mathrm{dL}$ \\
\hline $\mathrm{B}$ & $0,25 \mathrm{gram} / \mathrm{KgBB}$ & $\begin{array}{l}1 \\
2 \\
3 \\
\end{array}$ & \begin{tabular}{|l}
$13,10 \mathrm{~g} / \mathrm{dL}$ \\
$13,06 \mathrm{~g} / \mathrm{dL}$ \\
$13,08 \mathrm{~g} / \mathrm{dL}$ \\
\end{tabular} \\
\hline \multicolumn{3}{|l|}{ Rerata \pm SD } & $13,08 \pm 0,02 \mathrm{~g} / \mathrm{dL}$ \\
\hline $\mathrm{C}$ & 0,5 gram $/ \mathrm{KgBB}$ & $\begin{array}{l}1 \\
2 \\
3 \\
\end{array}$ & $\begin{array}{l}15,20 \mathrm{~g} / \mathrm{dL} \\
15,20 \mathrm{~g} / \mathrm{dL} \\
15,18 \mathrm{~g} / \mathrm{dL} \\
\end{array}$ \\
\hline \multicolumn{3}{|l|}{ Rerata \pm SD } & $15,19 \pm 0,01 \mathrm{~g} / \mathrm{dL}$ \\
\hline $\mathrm{D}$ & $1 \mathrm{gram} / \mathrm{KgBB}$ & $\begin{array}{l}1 \\
2 \\
3 \\
\end{array}$ & $\begin{array}{l}16,70 \mathrm{~g} / \mathrm{dL} \\
16,60 \mathrm{~g} / \mathrm{dL} \\
16,60 \mathrm{~g} / \mathrm{dL} \\
\end{array}$ \\
\hline \multicolumn{3}{|l|}{ Rerata \pm SD } & $16,63 \pm 0,05 \mathrm{~g} / \mathrm{dL}$ \\
\hline
\end{tabular}

Tabel 4. Rata-rata kadar hemoglobin selama 20 hari pemberian ekstrak bayam merah (Amaranthus tricolor .L) JURNAL BIOEDUKATIKA

VOL. 1 NO. 1

JULI 2013

HAL. 1 - 96 
Berdasarkan Tabel 4 terlihat bahwa rerata kadar hemoglobin tikus putih (Rattus norvegicus) terbesar selama 20 hari pemeliharan adalah pada perlakuan D (dengan dosis 1 gram/KgBB) dan kadar hemoglobin tikus putih (Rattus norvegicus) terkecil adalah pada perlakuan A (dengan dosis 0,125 gram/ $\mathrm{KgBB})$.

Untuk mengetahui pengaruh ekstrak air daun bayam merah (Amarantus tricolor L.) terhadap kadar hemoglobin pada tikus putih (Rattus norvegicus) dilakukan analisis regresi dengan hasil seperti yang terdapat pada Gambar 2.

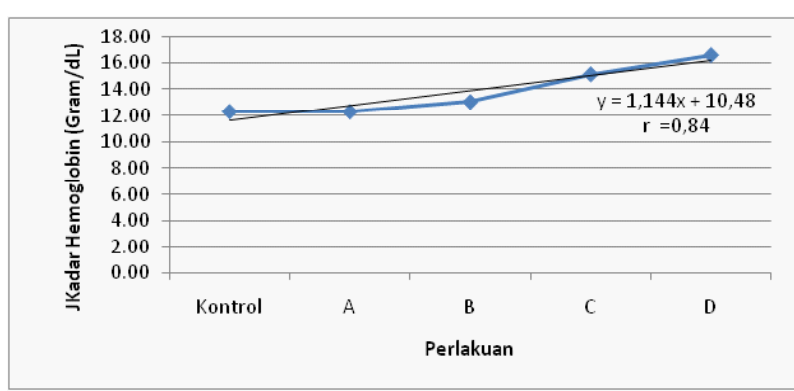

Gambar 2. Grafik hasil analisis regresi pengaruh ekstrak air daun bayam merah (Amarantus tricolor $L$.) terhadap kadar hemoglobin pada tikus putih (Rattus norvegicus)
Keterangan :

$\mathrm{K}:$ Kontrol

A : Ekstrak air daun baym merah1,25\% setara dengan dosis 0,125 gram $/ \mathrm{KgBB}$

B : Ekstrak air daun bayam merah 2,5\% setara dengan dosis 0,25 gram $/ \mathrm{KgBB}$

C : Ekstrak air daun bayam merah 5\% setara dengan dosis 0,5 gram $/ \mathrm{KgBB}$

D : Ekstrak air daun bayam merah $10 \%$ setara dengan dosis 1 gram $/ \mathrm{KgBB}$

Berdasarkan Gambar 2 dapat dilihat bahwa hasil penelitian menunjukkan hubungan linear sehingga memberi pengaruh positif terhadap ekstrak air daun bayam merah (Amarantus tricolor L.) terhadap jumlah kadar hemoglobin pada tikus putih (Rattus norvegicus). Bila dilihat dari gambar tersebut semakin tinggi dosis yang diberikan maka dapat meningkatkan kadar hemoglobin pada tikus putih (Rattus norvegicus).

Untuk mengetahui perbedaan antar perlakuan dilakukan analisis varian. Adapun ringkasan hasil anava rata-rata kadar hemoglobin disajikan pada Tabel 5.

\begin{tabular}{|c|c|c|c|c|c|}
\hline SV & DB & JK & KT & F hitung & F Tabel 5\% \\
\hline Perlakuan & 4 & 40,950 & 10,237 & 135,895 & 3,48 \\
\hline Galat & 10 &, 753 &, 075 & & \\
\hline Total & 14 & 41,703 & & & \\
\hline
\end{tabular}

Tabel 5. Hasil anava untuk rata-rata kadar hemoglobin pada tikus putih

Berdasarkan Tabel 5. Terlihat pada taraf uji 5\% pemberian ekstrak air daun bayam merah (Amarantus tricolor L.) terhadap kadar hemoglobin pada tikus putih (Rattus 80 norvegicus) dengan dosis yang berbedabeda menimbulkan perbedaan kadar hemoglobin yang berbeda-beda pula yang terbukti dengan nilai $\mathrm{F}$ hitung $(135,895)>\mathrm{F}$ Tabel

$$
\text { VOL. } 1 \text { NO. } 1 \text { JULI } 2013 \text { HAL. } 1-96
$$


$(3,48)$.

Untuk mengetahui kelompok-kelompok yang memiliki perbedaan yang nyata, maka dilanjutkan dengan uji LSD untuk mengetahui tingkat signifikasi antar kelompok perlakuan dan kontrol seperti pada Tabel 6 .

\begin{tabular}{|c|c|c|}
\hline $\begin{array}{c}\text { Per- } \\
\text { lakuan }\end{array}$ & $\begin{array}{c}\text { Rerata kadar } \\
\text { hemoglobin }\end{array}$ & $\begin{array}{c}\text { LSD5\%= } \\
1,35\end{array}$ \\
\hline A & 12,33 & $\mathrm{a}$ \\
\hline Kontrol & 12,34 & $\mathrm{~b}$ \\
\hline $\mathrm{B}$ & 13,08 & $\mathrm{c}$ \\
\hline $\mathrm{C}$ & 15,19 & $\mathrm{~d}$ \\
\hline $\mathrm{D}$ & 16,63 & $\mathrm{e}$ \\
\hline
\end{tabular}

Tabel 6. Hasil uji LSD kadar hemoglobin

Keterangan angka-angka yang diikuti oleh huruf yang berbeda :

$\mathrm{K}$ : Kontrol

A : Perlakuan $1,25 \%$ setara dengan dosis 0,125 gram $/ \mathrm{KgBB}$

B : Perlakuan $2,5 \%$ setara dengan dosis 0,25 gram $/ \mathrm{KgBB}$

$\mathrm{C}$ : Perlakuan $5 \%$ setara dengan dosis 0,5 gram/ $\mathrm{KgBB}$

D : Perlakuan $10 \%$ setara dengan dosis 1 gram/ $\mathrm{KgBB}$

Berdasarkan hasil uji LSD pada Tabel 6 menunjukkan bahwa sebagian perlakuan menunjukkan adanya beda nyata antar perlakuan. Hal ini berarti bahwa pemberian ekstrak air daun bayam merah (Amarantus tricolor L.) terhadap kadar hemoglobin pada tikus putih (Rattus norvegicus) dengan dosis yang berbeda-beda dapat menimbulkan perbedaan kadar hemoglobin yang berbeda-beda pula. Dari hasil uji LSD di atas maka pada kontrol (tanpa pemberian ekstrak), perlakuan A (1,25\%), perlakuan B (2.5\%) dapat dilihat ada beda nyata begitu juga dengan perlakuan C (5\%) dan perlakuan D (10\%).

\section{Pembahasan}

\section{Aklimasi}

Sebelum tikus putih (Rattus norvegicus) dimasukkan kegalam kandang terlebih dahulu tikus putih di aklimasi. Aklimasi ini bertujuan untuk mengetahui kemampuan bertahan hidupnya (survival rate) dan pengadaptasian hewan uji ke dalam pemberian ekstrak air daun bayam merah (Amarantus tricolor L.) yang diinginkan . Dari 15 ekor tikus putih (Rattus norvegicus) yang diaklimasi, ada sebanyak 15 ekor tikus putih tidak ada yang mengalami kematian, yang berarti pada aklimasi tikus putih menunjukkan kemampuan bertahan hidup 100\%. Hal ini tersebut sesuai dengan pendapat Smith dan Mangkoewidjojo (1988) bahwa tikus mudah untuk beradaptasi dengan lingkungannya yang baru.

\section{Jumlah eritrosit pada tikus putih (Rat- tus norvegicus)}

Perhitungan eritrosit pada tikus putih (Rattus norvegicus) sebanyak 15 ekor yang berumur 2,5 bulan dan diberi ekstrak air daun bayan merah (Amaranthus tricolor L.) dengan berbagai dosis yang berbeda-beda dihitung setelah 20 hari pemberian ekstrak air daun bayam merah (Amaranthus tricolor L.). Perhitungan jumlah eritrosit pada tikus putih bertujuan untuk mengetahui besarnya jumlah eritrosit pada tikus putih selama penelitian setelah diberi perlakuan yang berbeda-beda.

Berdasarkan Tabel 1 terlihat bahwa rerata eritrosit tikus putih (Rattus norvegicus) terbesar selama 20 hari pemeliharan adalah pada perlakuan D (dengan dosis 1 gram $/ \mathrm{KgBB}$ ) dengan 
jumlah eritrosit sebesar 9,32 x $106 / \mu \mathrm{L}$ sedangkan jumlah eritosit tikus putih (Rattus norvegicus) terkecil adalah pada Kontrol (tanpa pemberian ekstrak) sebesar $6,04 \times 106 / \mu \mathrm{L}$ pada kelompok kontrol jumlah eritrosit paling kecil diantara kelompok perlakuan yang lain dan membuktikan bahwa ekstrak air daun bayam merah mempengaruhi jumlah eritrosit.

Hal tersebut sesuai dengan penelitian selama 20 hari pemberian ekstrak air daun bayam merah (Amaranthus tricolor L.) berpengaruh terhadap jumlah eritrosit pada tikus putih. Jumlah eritrosit yang diperoleh dalam penelitian masih dalam jumlah eritrosit normal. Hal ini sesuai dengan pernyataan Smith dan Mangkoewidjojo (1988) bahwa jumlah eritrosit normal pada tikus adalah sebesar 7,2- 9,6 x $106 / \mu \mathrm{L}$.

Pada hasil analisis regresi (Gambar 1) dapat dilihat bahwa hasil penelitian menunjukkan hubungan linear sehingga memberi pengaruh positif yaitu semakin tinggi dosis ekstrak air daun bayam merah yang diberikan maka semakin tinggi pula jumlah eritrosit pada tikus putih.

Hal tersebut disebabkan karena daun bayam merah mengandung zat besi yaitu sebesar 2,2 mg (Rukmana, 1994) zat besi tersebut dapat meningkatkan jumlah eritrosit. Zat besi yang terdapat dalam bayam merah (Amaranthus tricolor L.) dapat membantu dalam pembentukan eritrosit. Hal tersebut sesuai dengan Budiyanto (2004) bahwa zat besi penting dalam tubuh dan berfungsi dalam membentuk sel-sel darah.

\section{Kadar hemoglobin pada tikus putih (Rattus norvegicus)}

Dalam perhitungan kadar hemoglobin ini, juga menggunakan tikus putih (Rattus norvegicus) sebanyak 15 ekor yang berumur 2,5 bulan dan diberi ekstrak air daun bayam merah (Amaranthus tricolor $L$.) dengan berbagai dosis yang 82 JURNAL BIOEDUKATIKA berbeda-beda dihitung setelah 20 hari pemberian ekstrak air daun bayam merah (Amaranthus tricolor L.). Perhitungan kadar hemoglobin pada tikus putih bertujuan untuk mengetahui besarnya kadar hemoglobin pada tikus putih selama penelitian setelah diberi perlakuan yang berbedabeda.

Berdasarkan Tabel 4 terlihat bahwa rerata kadar hemoglobin tikus putih (Rattus norvegicus) terbesar selama 20 hari pemeliharan adalah pada perlakuan $\mathrm{D}$ (dengan dosis 1 gram $/ \mathrm{KgBB}$ ) sebesar 16,63 g / dL dan kadar hemoglobin tikus putih (Rattus norvegicus) terkecil adalah pada perlakuan A (dengan dosis 0,125 gram $/ \mathrm{KgBB}$ ) yaitu 12,33 g / dL. Kadar hemoglobin pada perhitungan tersebut masih dalam kisaran normal. Hal tersebut sesuai dengan pendapat Smith dan Mangkoewijdojo (1988) bahwa kadar hemoglobin normal pada tikus putih berkisar antara 15$16 \mathrm{~g} / \mathrm{dL}$.

Tingginya kadar hemoglobin pada tikus putih membuktikan bahwa ekstrak air daun bayam merah (Amaranthus tricolor L.) berpengaruh terhadap kadar hemoglobin. Semakin tingginya kadar hemoglobin ini karena didalam daun bayam merah mengandung zat besi. Hal ini sesuai dengan pendapat Guyton (1990) bahwa zat besi dapat meningkatkan kadar hemoglobin.

Mekanisme zat besi yang berada di dalam molekul hemoglobin sangat penting untuk menjalankan fungsi pengikatan dan pelepasan oksigen. Dengan adanya molekul zat besi yang berada di dalam hemoglobin oksigen diikat dan dibawa. Kekurangan zat besi dapat menyebabkan jumlah hemoglobin juga akan berkurang dan oksigen yang dibawa pun juga akan berkurang pula (Sadikin, 2001).

Menurut Wartson (2002) bahwa sel darah merah tidak memiliki nukleus, tetapi berisi 
suatu protein khusus yang disebut hemoglobin. Hemoglobin adalah suatu pigmen berwarna kuning, tetapi efek keseluruhan hemoglobin adalah membuat darah berwarna merah. Hemoglobin mengandung sejumlah kecil besi dan besi ini esensial bagi kesehatan, meskipun jumlah totalnya di dalam darah dikatakan hanya cukup untuk membuat paku sepanjang 2 inci.

Hemoglobin memiliki daya tarik yang kuat terhadap oksigen. Ketika sel darah merah melewati paru-paru, hemoglobin akan bergabung dengan oksigen dari udara dan warnanya menjadi cerah. Hal ini menyebabkan warna darah yang teroksidasi menjadi merah cerah. Ketika sel darah merah melewati jaringan, oksigen dilepas dari darah dan hemoglobin menjadi keruh, sehingga darah berwarna merah keunguan.

\section{KESIMPULAN DAN SARAN}

\section{Kesimpulan}

Setelah dilakukan penelitian maka dapat disimpulkan beberapa hal sebagai berikut:

1. Ekstrak air daun bayam merah (Amarantuhus tricolor L.) berpengaruh terhadap jumlah eritrosit dan kadar hemoglobin pada tikus putih (Rattus norvegicus).

2. Dosis ekstrak air daun bayam (Amarantuhus tricolor $L$.) yang paling berpengaruh terhadap jumlah eritrosit dan kadar hemoglobin adalah pada perlakuan D yang setara dengan dosis 1 gram/KgBB.

3. Melalui metode pengkajian hasil penelitian tentang pengaruh ekstrak air daun bayam merah (Amaranthus tricolor L.) terhadap jumlah eritrosit dan kadar hemoglobin tikus putih (Rattus norvegicus) dapat dijadikan sumber belajar siswa SMA kelas XI dalam bentuk power point.

\section{Saran}

1. Perlu dilakukan penelitian lebih lanjut dengan menggunakan jenis hewan mamalia yang berbeda sehingga dapat diketahui dampak ekstrak air daun bayam merah (Amaranthus tricolor L.) yang cocok untuk berbagai jenis mamalia.

2. Perlu dilakukan penelitian lebih lanjut tentang kadar zat besi yang terdapat pada bayam sehingga sesuai dengan kadar zat besi yang dibutuhkan mamalia.

\section{DAFTAR PUSTAKA}

Anonin. 2009. Tanaman sayur. Universitas Gajah Mada. Yogyakarta.

.2009.http://media.Powerpoint.Wordpress..com/2010/03/Kekurangan.kelebihan Powerpoint

Backer.C.A \& Van den brink,R.C.B. 1965. Flora of java.N.V.P noorah off groniooen: The Netherlands

Dellmann \& Brown. 1989. Buku Teks Histology Veteriner: Jakarta

Frandson, RD. 1992. Anatomi dan Fisiologi Ternak IV. Gadjah Mada Press: Yogyakarta

Guyton, A.C. 1997. Fisiologi Kedokteran Edisi 9. Penerbit Buku Kedokteran: Jakarta

Kartolo S Wulangi. 1993. Prinsip-Prinsip Fisiologi Hewan. Depdikbut: Jakarta

Kusumawati, Diah. 2004. Bersahabat Dengan Hewan Coba. Gadjah Mada Press: Yogyakarta. 
Mulyasa, E. 2002. Manajemen berbasis sekolah konsep strategi \& implikasinya. PT Remaja Rosda Karya: Bandung

Pearce, E.C. 1985. Anatomi Dan Fisiologi untuk Paramedic. PT gramedia: Jakarta

Robert C Chiasson.1980. Laboratory anatomy Of White Rat Dubugoc Low: Wm C Brown Company Publisher

Rukmana Rahmat. 1994. Bayam.. Kanisius: Jakarta

Salimin. 2006. Media Power Point. PT Gramedia: Jakarta

Soedibyo, Moryati. 1998. Alam Sumber Kesehatan Manfaat\&Kegunaan. Balai pustaka: Jakarta

Soewolo,Soedjono,Basoeki dan Titi yuhadi. 1999. Fisiologis Manusia. IMSTEPJICA FMIPA universitas negri malang: Malang

Soewolo,Soedjono,Basoeki dan Titi yuhadi. 2000. Pengantar Fisiologi Hewan. Direktorat Jendral Pendidikan tinggi: Jakarta

Sudjana. 2003. Teknologi Pengajaran. Sinar Baru Argesindo. Bandung

Sudjoko. 2002. Pembelajaran Berbasis Sekolah. FPMIPA : UNY

Susilo, Muhammad Joko. 2004. Dasar-Dasar dan Proses Pembelajaran. LP2I press: Yogyakarta
Susilo, Muhammad Joko. 2006. Bekal Bagi Calon Guru Belajar dan Mengajar. LP2I press: Yogyakarta

Smith, J.B \& Mangkoewidjojo, S. 1988. Pemeliharaan, Pembuahan \& Penggunaan Hewan Percobaan Didaerah Tropis. Penerbit universitas Indonesia: Jakarta

Tjitrosoepomo, Gembong. 2004. Taksonomi Tumbuhan (Spermatophyta). Gajah Mada University: Yogyakarta

Watson., Roder, Biol. 1997. Analogi dan Fisiologi Untuk Perawat, EGC : Jakaarta

Winarno. 1991. Kimia Pangan Dan Gizi. Pustaka Sinar harapan: Jakarta 